\title{
Intraventricular Meningioma
}

National Cancer Institute

\section{Source}

National Cancer Institute. Intraventricular Meningioma. NCI Thesaurus. Code C5273.

A meningioma that affects the ventricles of the brain. 